\title{
The analysis of PPG Students' Mistake in Learning Daring Process
}

\author{
Ferry Ferdianto ${ }^{1}$, Jajo Firman Raharjo ${ }^{2}$, Sumar Hendayana ${ }^{3}$, \\ Asep Supriatna ${ }^{4}$, Arif Hidayat ${ }^{5}$ \\ \{ferry.ugj@gmail.com ${ }^{1}$ \} \\ Universitas Swadaya Gunung Jati ${ }^{1,2}$, Universitas Pendidikan Indonesia ${ }^{3,4,5}$
}

\begin{abstract}
Teacher Professional Education (PPG) is professional education in Higher Education after an undergraduate program that collects students in the field of work that requires special competence. The purpose of this research was to find out PPG students' mistake in learning daring process. The methode used for this research is descriptive qualitative from chat in daring learning. The analysis of PPG students' mistake used the instrument of chat in daring learning process. The module 6 in daring learning process consists of 4 learning competencies that consist of 2 topics in learning daring process. The result showed that majority of the students have responded to the topic presented by the instructor, while few of them made mistakes in answering the topic of the problem given by the instructor. Students make reading mistakes and misunderstanding, reading stage students' cannot interpret the sentences they read well, understand problems (comprehension).
\end{abstract}

Keywords: Analysis Of Students' Mistake, Ppg, Reading Mistakes, Comprehension

\section{Introduction}

The mandate of Law Number 14 of 2005 concerning Teachers and Lecturers article 8 concerning Teachers must have academic qualifications, competencies, educator certificates, physically and mentally healthy, and have the ability to create national educational goals. Improving the quality of education is supported by the quality of teachers, qualified teachers are professional teachers who can improve the quality of the education process. Improving the quality of the education and learning process is expected to produce challenges that were available in the past of the industrial revolution 4.0,

Teacher Professional Education Program dalam jabatan [1], and then referred to as Teacher Professional Education Program (PPG) dalam jabatan is an educational program held to improve the qualifications of teachers graduating from S1 Education and S1 / D IV NonEducation who have served as teachers in order to fully master teacher competence in accordance with national education standards so as to obtain a certificate of professional educators in early childhood education, basic education and secondary education.

The purpose of PPG is to produce teacher candidates who have competence in planning, implementing, and evaluating learning; follow up on the results of the assessment by mentoring, and training students; and able to conduct research and develop professionalism on an on going [2]. The PPG program provides deeper learning and experience to become 
professional teachers, professional development of teachers, often called in-service education or staff development, has been conducted for different purposes and in different forms [3].

Teaching skills possessed by a teacher come from the learning process at the Educational Workforce Education Institute (LPTK). LPTK becomes a place of education for students who want to work as teachers [4]. FKIP Universitas Swadaya Gunung Jati (UGJ) is one of the LPTK that has the confidence to carry out PPG activities in positions for region III and surrounding areas. The PPG program in the office announced by the government has indeed been carefully designed by considering it from various aspects, namely philosophical, historical, juridical, and conceptual. [5]. The PPG program uses an online system in its learning process as an effort to deal with the demands of the industrial revolution 4.0. the industrial revolution 4.0 is demanded to be more innovative and effective, so that it will have an impact on the ability of prospective teachers to anticipate future education. Thus, learning must be able to equip teachers or lecturers with strategies or effective steps to improve the quality of learning, one of which is through Lesson Study.

Lesson study is a direct translation of the term jugyokenkyu, in Japanese the word jugyo means study and kenkyu means study or research [6]. Through lesson study, we can work towards increasing learning by looking at learners' learning patterns. Lesson study provides a better understanding of how students learn and lecturers teach, in implementing learning Lesson Study improves the quality of learning systematically and comprehensively, through innovative learning methods, learning media, and pedagogical knowledge building, where lecturers can learn from students. [7]. The results of the study [3] revealed that the teachers involved in lesson study had improved their learning. Lesson Study as a teaching strategy is able to produce teacher professionalism, productivity in Teaching and skills in Trainees [8], Teaching is seen as an interactive process in student learning and content is put together through effective teacher facilitation [9]. The aim of the Lesson Study approach is to professionalize the teacher by designing, observing, implementing and evaluating two research lessons [10].

Lesson Study results are not limited to what students have learned in class and post-class reflective discussions. [11, 12]. Participatory roles are needed as facilitators of research meetings but are also needed as equitable participants in the community as the community of practice develops to enable the sustainability of the professional development model [13]. lesson study results do not fully describe teacher services to students through reflection.

The results showed that, the teacher developed high mastery of subject matter, confidence through metacognition analysis, dexterity in pedagogical skills, and this had a significant positive effect on students. [8]. Research findings show that the LS model strengthens teachers' understanding of educational planning, their interactions with colleagues, peer-topeer learning, and their questioning skills. [14]

\section{Methodology}

The research method used in this study is a qualitative descriptive method, with research subjects used are PPG students dalam jabatan on assessment material (module 6). Module 6 has four learning competencies (KB), where each learning completeness has an average of two problem topics delivered by lecturers to students. (1) M6 KB1 Topic 1 material for Measurement, evaluation and evaluation, (2) M6 KB1 Topic 2 material for implementing procedures for measuring, evaluating, and evaluating, (3) M6 KB2 Topic 1 for Authentic 
Assessment material, (4) M6 KB2 Topic 2 material carry out authentic assessment, (4) M6 KB3 Topic 1 material makes Scores and Determining Subjective Test Values, (5) M6 KB3 Topic 2 writing material Test Learning, (6) M6 KB4 Topic 1 material examines the test of learning outcomes, (7) M6 KB4 Topic 2 of the material examines learning outcomes tests (how do you determine the KKM?). The learning process used can be seen in Figure 1.

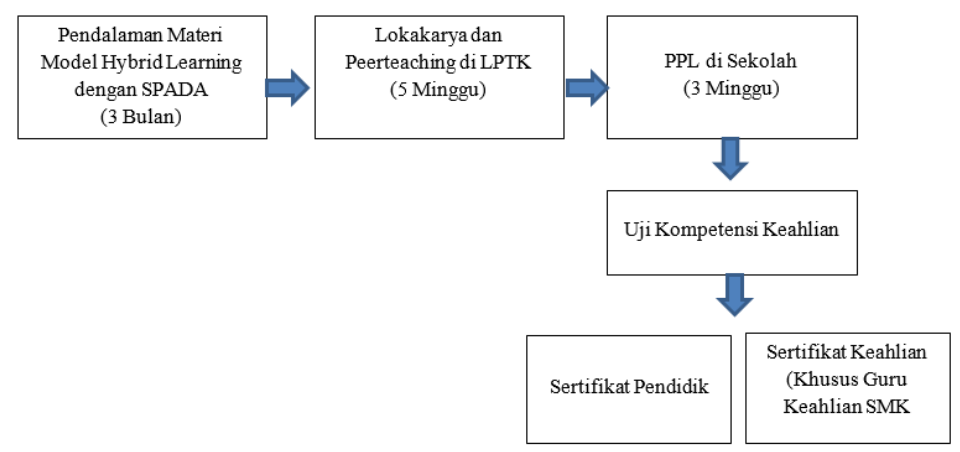

Fig. 1. PPG Dalam Jabatan Activities

Based on Figure 1, it can be seen that the learning process begins with online learning for 3 months, during this online learning process an error analysis of the students is done in answering the topic of problems raised by the lecturer. Every conversation from students towards the response of questions from the lecturer we note where the error lies. Errors made by students are analyzed and grouped into 5 categories, namely (1) errors in the aspect of understanding, (2) responses, (3) applied, (4) difficulties / errors are found, and (5) questions are not answered [15]. After carrying out online PPG activities continued with workshops at the Gunung Jati Swadaya University as a place for PPG implementers. Before competency testing activities the students must carry out PPL activities at school for 3 weeks.

\section{Result and Discussion}

Based on data from conversations between students and lecturers during the online learning process that lasted for 3 months, the results of the error analysis conducted on students are grouped into 5 categories. Next we submit the results of grouping students' mistakes during the learning process.

In Figure $2 \mathrm{~KB} 1$, it can be seen that in the material measurement, assessment, and evaluation of students who made the biggest mistake in responding to the first problem, namely about the description of measurement, assessment, and evaluation, mistakes made by students are errors in aspects of student responses to the problems given by lecturers by $57 \%$, while in the aspects of understanding and applied there were no mistakes. And in the second problem concerning how the procedures for carrying out measurement, assessment, and evaluation of the biggest mistakes made by students are errors in the aspect of understanding. 


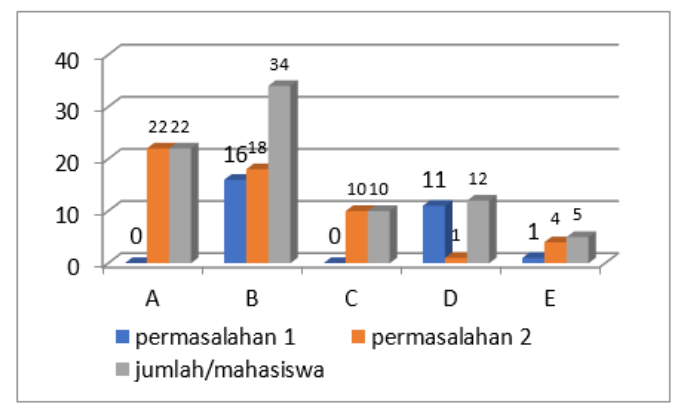

Fig. 2. Student Analysis M6 KB 1 Topik 1

In Figure 3 there were almost no errors in the aspects of understanding, response aspects, applied aspects, and students who did not answer only a little in other words found no difficulties in KB 1 on topic 2 (procedures for carrying out measurements, assessments, and evaluations).

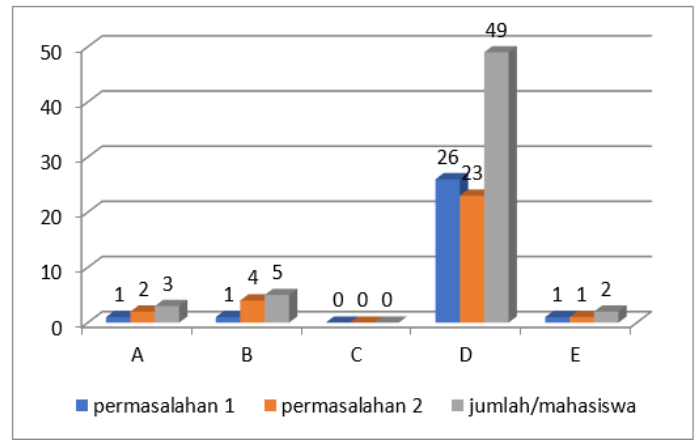

Fig. 3. Student Analysis M6 Kb 1 Topik 2

Figure 4 shows that in problem 1 (authentic assessment description) the error occurred was $42 \%$ in the response aspect and the rest had no difficulty answering problem 1 . While in problems 2, 3, and 4 there were many students who did not answer questions from the lecturer.

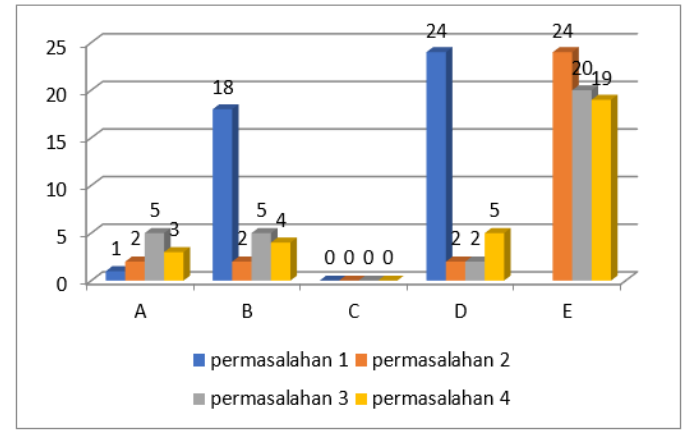


Fig. 4. Student Analysis M6 KB2 Topics 1

Figure 5 shows that problem 1 for mistakes in the aspects of response and application of students did not experience problems only about $30 \%$ of students made mistakes in understanding aspects, as well as for the second problem. While students who did not answer the problems raised by lecturers in the first problem were $26 \%$ and $43 \%$ for the second problem concerning the implementation of authentic assessment.

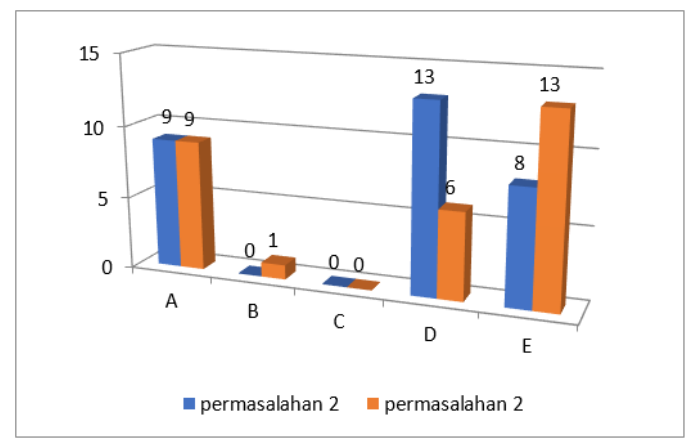

Fig. 5. Student Analysis M6 KB2 Topik 2

Figure 6 shows that students who made mistakes aspects of the response to the problems given by the lecturer, namely is the score obtained by students directly entered into the list of grades? And does the student after being able to score mean that as the value of student learning? the magnitude of errors in the response aspects for the two problems above (problems 2 and 3 ) is $30 \%$. As for errors on the understanding and applied aspects there are no errors. And students who did not answer the problems raised by lecturers were $60 \%$. As for the problem, how do you score and determine subjective test scores? There was an error in the aspect of understanding by $50 \%$, in the response aspect by $63 \%$, and in the applied aspect by $23 \%$, the rest were students who did not answer and had no difficulty with the 3 problems raised by the lecturer.

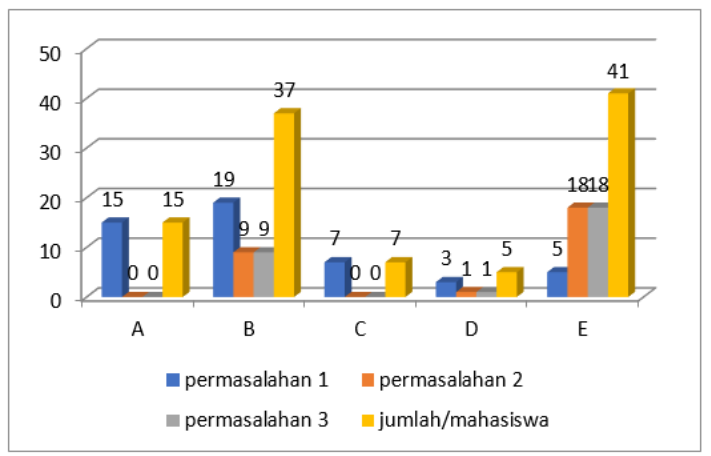

Fig. 6. Student Analysis M6 Kb 3 Topics I 
The problems raised by the lecturer about the steps taken in writing the learning test in Figure 7 can be seen that students do not have much difficulty in answering problems, but there are about $30 \%$ of students who still make mistakes in the aspect of responses, and 57\% of participants students have no difficulty in answering lecturer problems. Similar to problem 1, in problem 2 regarding giving a brief explanation of the steps (follow-up questions), $30 \%$ of students made mistakes in the aspect of responses, $23 \%$ of students had no difficulty with the problem, and the rest of the students did not answer to given problem.

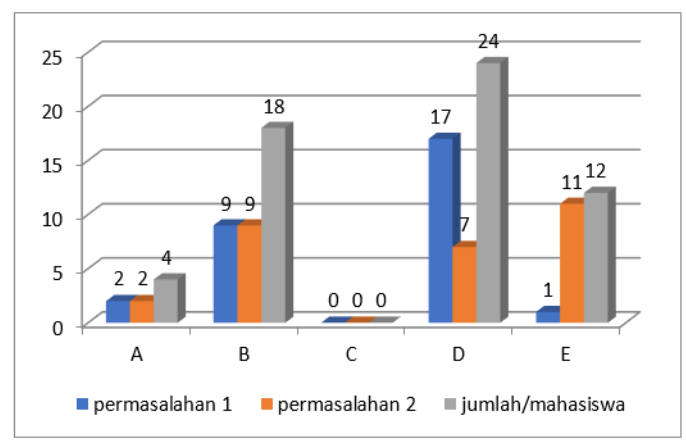

Fig. 7. Student Analysis M6 Kb 3 Topics 2

Mistakes made by students in answering problems on M6KB4 topic 1 as shown in Figure $\mathbf{8}$, the problem of errors in understanding aspects is $73 \%$, which means that many students do not test the questions before the test questions are given to their students.

In Figure 9 it can be seen that $80 \%$ of students make mistakes in the aspects of understanding, and mistakes in the aspect of responses by $43 \%$ on the problem of how students determine the amount of KKM used in subjects in their respective schools.

Based on Figure 10 it can be seen that in topic 1 about the procedures for implementing measurement, assessment and evaluation of learning competence 1 the most mistakes made by students are errors in the aspect of responses, and very few students who do not answer the problems raised by lecturers. While on topic 2 regarding the procedures for carrying out measurements, assessments and evaluations there were no errors found in students in providing responses.

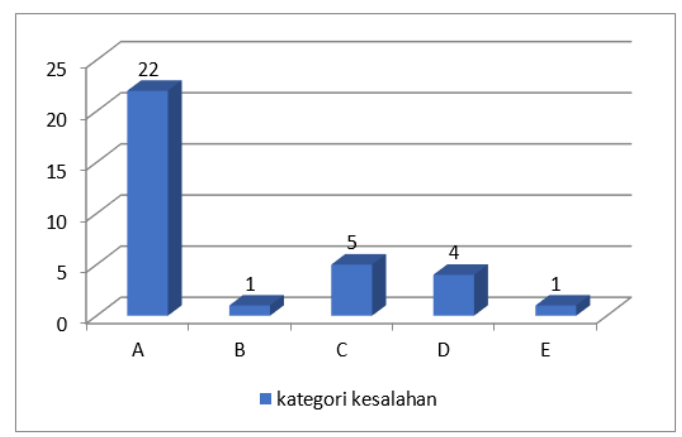

Fig. 8. Student Analysis M6 KB4 Topics 1 


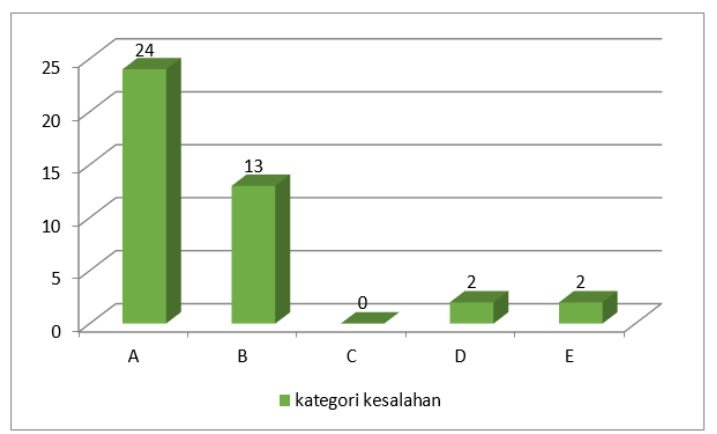

Fig. 9. Student Analysis M6 KB4 Topics 2

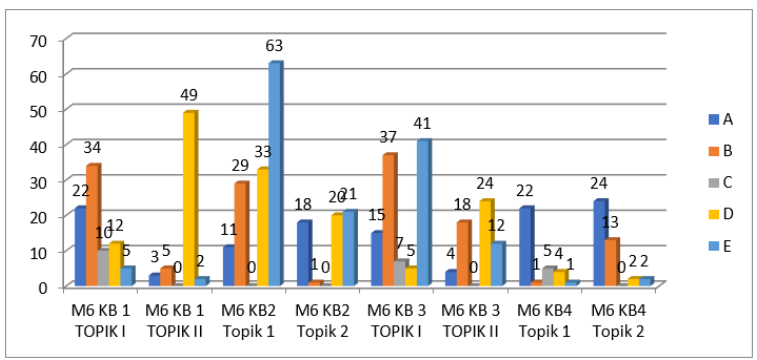

Fig. 10. Recapitulation of Student Error Analysis

Regarding authentic assessment materials many students did not answer questions from the lecturer, and there were no students who did the problems in applied aspects. As many as $21 \%$ of students made mistakes in the aspect of responses, and $22 \%$ of students did not answer the questions given. While on KB2 topic 2 about authentic assessment getting a relatively low percentage, the results of the analysis showed that students who made mistakes in the response and applied aspects did not exist, and students who did not experience difficulties by $13 \%$, as well as students who did not answer by $14 \%$.

On KB 3 topic 1 regarding Making Scores and Determining Subjective Test Scores, many students did not answer, many students made mistakes on the aspect of responses by $27 \%$.. different from topic 2 about writing learning tests, students did not experience much difficulty , only made a mistake in the response aspect that is equal to $13 \%$.

Error analysis on KB4 written material test results of learning outcomes and study learning outcomes, in this case is how to determine the $\mathrm{kkm}$ value made by students while in school, errors on the aspect of pemahan much done by students on both topics, for other aspects of error is very low. 


\section{Conclution}

During the online learning process in the ppg program, students make mistakes which are grouped into five groups, Errors in the aspects of understanding, Errors in the aspects of responses, errors in the applied aspects, No difficulties or errors found, and No answer. The errors on the highest aspects of understanding are found in KB 1 Topic 1 namely the material Measurement, assessment, and evaluation, KB 4 Topics 1 and 2 namely about Studying the test of learning outcomes. Error aspects of responses made a lot of students on KB 1 Topic 1 material Measurement, assessment, and evaluation, KB 2 topic 1 about Authentic Assessment, and KB 3 Topic 1 about Making Scores and Determining Subjective Test Values. Student mistakes do not make many mistakes in the aspects of application for all learning competencies. While students have no difficulty at all in the material implementation procedures for measurement, assessment, and evaluation (KB 1 Topic 2), and students do not answer questions from lecturers on KB 2 and KB 3 topic 1 namely material Authentic Assessment and Making Scores and Determining Subjective Test Score.

Aknowledgement. This research is funded by Directorate of Research and Community Service RISTEK DIKTI Funding Year of 2019.

\section{Reference}

[1] Permendikbud Peraturan menteri pendidikan dan Kebudayaan Nomor 9 tahun 2009 Tentang penetapan buku teks pelajaran yang memenuhi syarat kelayakan untuk digunakan dalam proses pembelajaran (2019)

[2] Direktorat Jenderal Pembelajaran dan Kemahasiswaan. Pedoman Penyelenggaraan Program Pendidikan Profesi Guru Jakarta: Direktorat Jenderal Pembelajaran dan Kemahasiswaan Kementerian Riset, Teknologi, dan Pendidikan Tinggi (2008)

[3] Ono, Y., \& Ferreira, J.: A case study of continuing teacher professional development through lesson study in South Africa. South African Journal of Education, Vol. 30, No. 1 (2010)

[4] Kisrianto and Iriani C.: Persepsi Mahasiswa Program Pendidikan Profesi Guru (PPG) Pendidikan Sejarah Terhadap Program PPG. Jurnal PENDIDIKAN SEJARAH Vol. 7 No. 1 Januari 2018 pp 66-77 (2018)

[5] Margi and Atmadj: Program Pendidikan Profesi Guru Prajabatan Dalam Perspektif Darwinisme Sosial. Jurnal Pendidikan dan Pengajaran, Vol. 46, No. 1, pp. 87-95 (2013)

[6] Gutierez, S. B.: Collaborative professional learning through lesson study: Identifying the challenges of inquiry-based teaching. Issues in Educational Research, Vol. 25, No. 2, 118 (2015)

[7] Gunawan, I. I.: The Application of Instructional Management Based Lesson Study and its Impact with Student Learning Achievement. In 2nd International Conference on Educational Management and Administration (CoEMA 2017). Atlantis Press (2017)

[8] Akinwamide: A 3-Way Paradigm of Lesson Study Strategy on Teachers' Productivity, Teaching Profession and Trainee Proficiency: A Contemporaneous Paradigm. International Journal of English Language Teaching Vol.6, No.7, pp.10-16 (2018)

[9] Hart, L. C., Alston, A. S., \& Murata, A.: Lesson study research and practice in mathematics education (p. 10). Dordrecht: Springer (2011)

[10] Pjanić, K. The origins and products of Japanese lesson study. Inovacije u nastavi-časopis za savremenu nastavu, 27(3), 83-93 (2014)

[11] Verhoef, N. C., \& Tall, D. O.: Lesson study: the effect on teachers' professional development. In 35th Conference of the International Group for the Psychology of Mathematics Education (PME) (2011) 
[12] Myers, J.: Lesson Study as a Means for Facilitating Preservice Teacher Reflectivity. International Journal for the Scholarship of Teaching and Learning, Vol. 6, No. 1 (2012)

[13] Shúilleabháin, A. N.: Lesson Study in a Community of Practice: A model of in-school Professional Development. Trinity Education Papers, Vol. 2, No. 1, 22-40 (2013)

[14] Dogan, Z. Y., \& Altun, S.: The Effects of the Research Lesson Study (RLS) Model on Teachers' Professional Development. International Online Journal of Educational Sciences, 10(3) (2018)

[15] Alhassora, N. S. A., Abu, M. S., \& Abdullah, A. H.: Newman error analysis on evaluating and creating thinking skills. Man in India, 97, 413-27 (2017) 